\title{
Comparative Analysis of Different Carboxylic Leaching Agents for Lead Battery Recycling
}

\author{
Lina Villa ${ }^{1}$, Nestor Rojas ${ }^{2}$, Wilmer Saldarriaga ${ }^{3}$ \\ ${ }^{1,3}$ Ceramic and vitreous Materials Laboratory, National University of Colombia \\ Medellin, A.A 568 \\ ${ }^{1,2}$ Faculty of Mines, National University of Colombia- Medellin \\ Street 59 A N 63-20, Medellin, Colombia \\ lcvillav@unal.edu.co; nrrojasr@unal.edu.co; wjsaldarriagaa@unal.edu.co
}

\section{Extended Abstract}

Lead batteries account about $60 \%$ of the world's electric power storage batteries. An automobile lead battery weighing approximately $17 \mathrm{Kg}$ contains 35\% lead paste and 29\% lead. About 50\% of the world's lead consumption derive from recycled and reused materials [1]. Currently, pyrometallurgical methods account for more than $90 \%$ of lead recovery technology. However, they are severely criticized because the emission of sulfur dioxide by decomposing lead sulphate at elevated temperatures in addition to emissions of particulate matter [2].

The lead recovery from the recycling of batteries by hydrometallurgical processes has been investigated as an alternative to the pyrometallurgical processes. Therefore, a comparative thermodynamic analysis was studied by leaching of lead from carboxylic leaching agents (Citrate, Acetic, oxalic, EDTA and NTA). Three levels conditions were established, varying the concentration factors and $\mathrm{S} / \mathrm{L}$ ratio, setting the temperature, $\mathrm{pH}$ and agitation speed. Hydrazine was used as reducing agent and hydrogen peroxide as oxidizing agent [3]. Also, the behaviour of lead at electrolysis step was analyzed.

The results obtained showed recoveries of up to $90 \%$ in the above-mentioned conditions, being Citrate the leaching agent with greater efficiency.

\section{References}

[1] A. Smaniotto, A. Antunes, I. D. N. Filho, L. D. Venquiaruto, D. de Oliveira, A. Mossi, M. Di Luccio, H. Treichel, and R. Dallago, "Qualitative lead extraction from recycled lead-acid batteries slag.," J. Hazard. Mater., vol. 172, no. 2-3, pp. 1677-80, 2009.

[2] M. S. Sonmez and R. V. Kumar, "Leaching of waste battery paste components. Part 1: Lead citrate synthesis from $\mathrm{PbO}$ and $\mathrm{PbO}$," Hydrometallurgy, vol. 95, no. 1-2, pp. 53-60, 2009.

[3] R. Zárate-Gutiérrez and G. T. Lapidus, "Anglesite (PbSO4) leaching in citrate solutions," Hydrometallurgy, vol. 144-145, pp. 124-128, 2014. 